\title{
IMPLEMENTASI KONSEP COMPACT CITY PADA BWK I KOTA SURAKARTA
}

\author{
Wilda Mazidaturrizka ${ }^{1}$, Paramita Rahayu ${ }^{1}$, Kuswanto Nurhadi $^{1}$ \\ ${ }^{1}$ Program Studi Perencanaan Wilayah dan Kota, Fakultas Teknik, Universitas Sebelas Maret
}

\begin{abstract}
Abstrak
Compact city atau kota yang kompak merupakan suatu konsep untuk mengelola pertumbuhan kota agar lebih efisien dengan menerapkan pembangunan intensif dengan guna lahan campuran, sehingga dapat mereduksi perjalanan penduduk kawasan. Konsep compact city menjadi solusi untuk menjawab tantangan isu-isu pertumbuhan kota yang meluas secara horizontal, seperti kepadatan yang kurang merata, penyediaan sarana dasar yang kurang memadai, serta isu-isu terkait pergerakan penduduk. Isu-isu tersebut kemudian menjadi tantangan pada BWK I Kota Surakarta, sehingga penelitian ini ditujukan untuk mengukur potensi implementasi konsep compact city pada BWK I Kota Surakarta yang diharapkan dapat menjadi solusi dari isu-isu tersebut. Potensi implementasi compact city ini diukur dari variabel penggunaan lahan, pelayanan sarana dasar dan kepadatan kawasan dengan menggunakan pendekatan kuantitatif dengan skoring skala Guttman. Penggunaan lahan yang dapat mendukung potensi implementasi compact city adalah penggunaan lahan campuran. Pada BWK I Kota Surakarta, penggunaan lahannya cenderung tidak memenuhi kriteria campuran pada sebagian besar kawasan. Kemudian dari segi pelayanan dasar, pada konsep compact city harus dapat mencakup keseluruhan kawasan. Sedangkan, pada BWK I Kota Surakarta masih ada beberapa jenis sarana dasar yang cakupannya tidak memenuhi keseluruhan kawasan. Terakhir, untuk kepadatan kawasan, pada compact city harus memenuhi standar kepadatan tinggi. Sedangkan, BWK I Kota Surakarta secara keseluruhan belum dapat dikategorikan sebagai kepadatan tinggi. Maka dari itu, hasil keseluruhan potensi implementasi compact city pada BWK I Kota Surakarta bernilai $44 \%$ dari 100\%, yang berarti belum menunjukkan potensi penerapan konsep compact city. Namun, tidak menutup kemungkinan bisa dilakukan implementasi compact city dikemudian hari, jika dilakukan beberapa penyesuaian pembangunan kota terhadap kriteria konsep compact city.
\end{abstract}

Kata kunci: compact city; kepadatan; pelayanan sarana dasar; penggunaan lahan campuran

\begin{abstract}
Compact city is a concept to manage urban growth to be more efficient by implementing intensive development with mixed land uses, so as to reduce the travel of residents in the area. The concept of compact city is a solution to address the challenges of urban growth issues that expand horizontally, such as uneven density, inadequate provision of basic facilities, and issues related to population movement. These issues then become challenges to BWK I Kota Surakarta. This research aims at investigating the potential implementation of the compact city concept at BWK I Kota Surakarta that is expected to offer solution to these issues. The potential for compact city implementation is measured from the variables of land use, urban facilities and density using a quantitative approach with a Guttman scale. Land use that can support the compact city implementation is a mixed land use. Land use of most areas in BWK I Kota Surakarta, tends to be dominated by a single use. For basic services, the service area of urban facilities should encompass the entire area of the city. For BWK I Kota Surakarta several urban facilities do not fulfill this requirement. Finally, for area density, a compact city must meet the criteria of high density. BWK I Kota Surakarta does not fall into that category of density. Therefore, the overall score of Gutman Scale from the variables of compact city shows th score that similar to $44 \%$ out of $100 \%$, which means the BWK has not yet indicate its potential to be the area for developing the compact city concept. However, it remains possible to implement the concept in the future, if some adjustments to the area in accordance to the compact city's variable's requirement.
\end{abstract}

Keywords: basic services; compact city; density; mixed land use 


\section{PENDAHULUAN}

Compact city atau kota yang kompak merupakan suatu konsep manajemen pertumbuhan kota yang diperkenalkan oleh George Dantzig dan Thomas L. pada tahun 1973 yang didasari oleh keinginan untuk efisiensi dalam konsumsi sumberdaya dan kebutuhan bertahan hidup manusia (Saaty \& De Paola, 2017). Kemudian, konsep compact city semakin berkembang dalam konteks perencanaan dan perancangan kota sebagai kritik terhadap fenomena urban sprawl. Urban sprawl merupakan fenomena perkembangan kota yang dianggap tidak berkelanjutan (sustainable) karena terjadi secara meluas, acak dan tidak terencana, dengan melibatkan konversi lahan di daerah pinggiran (Hanief \& Dewi, 2014). Compact city kemudian menjadi kritik terhadap urban sprawl karena konsepnya yang menitikberatkan pada manajemen kota dengan kepadatan tinggi dan penggunaan lahan campuran, serta dilengkapi fasilitas sistem transportasi umum yang baik demi mencapai kesejahteraan sosial dan keberlanjutan kehidupan kota (Jacobs, 1961).

Kota Surakarta memiliki kepadatan yang cukup tinggi, yaitu 11.219 jiwa/km²(Badan Pusat Statistik, 2018). Kepadatan yang cukup tinggi tersebut dapat memicu isu-isu perkotaan terutama dalam konteks penggunaan lahan yang semakin tidak terkendali karena tingginya tingkat aktivitas penduduknya. Bagian Wilayah Kota (BWK) pada Kota Surakarta yang aktivitas penggunaan lahan serta kepadatannya tergolong tinggi, yaitu BWK I yang mencakup Kecamatan Pasar Kliwon dan Serengan. Hal ini menyebabkan isu perkotaan yang cukup krusial pada Kota Surakarta muncul pada BWK I, yaitu isu terkait permukiman padat. Kemudian dari segi lokasi, BWK I terletak di selatan Kota Surakarta yang berbatasan langsung dengan Kabupaten Sukoharjo. Hal ini kemudian menimbulkan isu pertumbuhan kota yang meluas, yang juga dipengaruhi oleh pusat aktivitas baru pada Kabupaten Sukoharjo, yaitu daerah Solo Baru.

Kepadatan yang tinggi dan pertumbuhan kota yang meluas ini memicu munculnya isu-isu perkotaan pada BWK I, seperti potensi terjadi kemacetan serta fenomena urban sprawl. Adanya isu-isu tersebut, hingga sekarang belum didukung dengan strategi/kebijakan dari pemerintah setempat untuk mengantisipasi dan menyelesaikan masalah yang ada secara spesifik. Oleh sebab itu, Kota Surakarta khususnya BWK I diharapkan dapat menerapkan pengelolaan perkotaan yang mengacu pada konsep compact city yang berpotensi untuk menyelesaikan isu-isu perkotaan yang terkait kepadatan, kemacetan, dan sebaran fasilitas yang tidak merata. Berdasarkan kondisi tersebut, maka penelitian ini dilakukan untuk mengetahui bagaimana potensi untuk dilakukan implementasi konsep compact city pada BWK I Kota Surakarta.

\section{KAJIAN PUSTAKA}

Penelitian ini menggunakan teori-teori yang relevan terkait compact city sebagai dasar untuk perumusan variabel yang kemudian akan dianalisis untuk mendapatkan hasil akhir potensi implementasi compact city pada BWK I Kota Surakarta. Berikut merupakan penjabaran teori-teori tersebut.

\subsection{PERTUMBUHAN KOTA (URBAN GROWTH)}

Kota menurut Adisasmita (2006), secara umum merupakan suatu wilayah dengan pemusatan penduduk dan berbagai jenis kegiatan ekonomi, sosial budaya, serta administrasi pemerintahan. Menurut Rapoport dalam Zahnd (2006), kota dilihat secara lebih spesifik merupakan suatu pemukiman yang relatif besar, padat, dan permanen, terdiri dari kelompok individu yang heterogen dari segi sosial. Seiring dengan berjalannya waktu, kota semakin berkembang karena heterogenitas dari unsur-unsur di dalamnya yang memaksa kota untuk dapat memenuhi kebutuhannya. Perkembangan kota ini juga dapat terjadi seiring dengan proses migrasi ke kota serta proses transformasi menjadi area perkotaan. Selain perkembangan, kota juga mengalami pertumbuhan (urban growth). Pertumbuhan kota tidak hanya dilihat sebagai satu entitas perkembangan ruang, namun juga dapat merujuk kepada sesuatu yang lebih besar, yaitu mendukung perkembangan ekonomi dari suatu wilayah atau negara. Oleh karena itu, penting untuk mengatur perkembangan kota agar dapat berjalan dengan efektif dan efisien. Menurut Basse dalam Horn (2015), perencanaan ruang dalam hal ini dituntut untuk mampu mengakomodasi perkembangan kota serta wilayah sekitarnya, dengan memperhatikan kemampuan lahan dan aktivitas di atasnya yang ramah lingkungan, serta meningkatkan kondisi ekonomi dan sosial masyarakatnya secara berkelanjutan. 


\subsection{URBAN SPRAWL}

Kota tumbuh dan berkembang sangat cepat karena perkembangan ekonomi yang cepat. Pertumbuhan kota bertambah seiring dengan tingkat pendapatan daerah tetapi menurunnya kualitas lingkungan. Jika kota berkembang dan tumbuh tanpa perencanaan yang baik, maka terjadilah fenomena urban sprawl (Desiyana, 2017). Menurut Setioko (2009), sprawl dideskripsikan sebagai pembangunan yeng tidak terencana, menyebar, kepadatan rendah dan tidak terstruktur di kawasan pinggiran. Salah satu bentuk nyata dari proses urban sprawl di kawasan pinggiran adalah meningkatnya jumlah pembangunan perumahan yang tersebar di kawasan pinggiran kota. Adanya pembangunan perumahan tersebut, otomatis membuat jaringan jalan menjadi bertambah, dan muncul aktivitas ekonomi, seperti komersial. Perembetan bentuk fisik kekotaan ini menyebabkan adanya perubahan bentuk kota. Sedangkan menurut Soetomo dalam Hanief (2014), urban sprawl merupakan proses perkembangan model ekstensi urbanisasi dalam proses pembentukan "mega urban" secara horizontal. Menurut Geyer dalam Horn (2015), pertumbuhan kota yang terjadi secara meluas seperti urban sprawl ini banyak dianggap buruk dan tidak berkelanjutan, sedangkan pertumbuhan kota dengan densifikasi penggunaan lahan dianggap dapat menjadikan suatu kota lebih berkelanjutan.

\subsection{COMPACT CITY}

Menurut Geyer dalam Horn (2015), konsep densifikasi lahan dianggap sebagai suatu bentuk manajemen pertumbuhan kota yang baik. Densifikasi lahan pada perkotaan ini juga menjadi dasar dari konsep compact city. Compact city atau kota yang kompak merupakan suatu bentuk manajemen pertumbuhan kota yang memusatkan penggunaan lahan dan aktivitasnya pada pusat kota dan menarik aktivitas serta guna lahan lainnya mendekati pusat kota tersebut, sehingga tercipta suatu ruang atau wilayah yang padat. Hal tersebut mengakibatkan penggunaan ruang pada suatu wilayah kota menjadi mixed-use. Menurut Neuman dalam Horn (2015), penggunaan mixed-use ini dianggap mendukung lingkungan yang positif dan berkelanjutan. Menurut Jenks et. al (1996), compact city juga dilihat sebagai solusi untuk mewujudkan lingkungan yang berkelanjutan atau sustainable dengan menitikberatkan pada 3 aspek, yaitu bentuk kota yang terpusat (centralization urban form), sistem transportasi yang efisien dan kualitas hidup (quality of life). Bentuk kota yang mengindikasikan konsep compact city adalah bentuk kota yang terpusat, yang mana akan menghasilkan high density compact living atau tempat tinggal yang kompak dengan kepadatan yang tinggi jika dilihat dari guna lahan serta kepadatan bangunannya (Jenks et al., 1996). Menurut Burton dalam Jensen et. al (2011), bentuk kota yang terpusat memiliki indikator dari kepadatan (density), keberagaman fungsi (mix function) dan intensifikasi (intensification). Pada konsep compact city, faktor yang lebih ditekankan adalah kepadatan dan keberagaman fungsi, yang mana ini mengindikasi kepada kepadatan kawasan dan penggunaan lahan campuran.

Aspek selanjutnya yang dapat mendukung implementasi compact city adalah sistem transportasi yang efisien. Menurut Burgess dalam Jenks et. al.(2000), sistem transportasi yang efisien dibutuhkan untuk mendukung compactness atau kekompakan dari suatu kota, untuk mengurangi mobilitas kendaraan pribadi yang kemudian akan mengurangi isu-isu transportasi perkotaan. Aspek sistem transportasi yang efisien ini sangat berkaitan dengan aspek bentuk kota yang terpusat untuk pada konsep compact city. Bentuk kota terpusat dengan penggunaan lahan campuran cenderung dikaitkan dengan jarak perjalanan rata-rata yang lebih rendah untuk semua moda, seperti peningkatan penggunaan angkutan umum dan peningkatan kelayakan jalan kaki dan bersepeda. Oleh karena itu, lingkungan perkotaan yang kompak juga cenderung lebih bercampur dalam penggunaan lahan mereka, bukan terpisah-pisah oleh kategori, seperti di daerah pinggiran kota dengan kepadatan rendah. Ini semakin meningkatkan pengurangan panjang perjalanan dan viabilitas mode transit dan moda tidak bermotor yang sejalan dengan definisi dari compact city (Bramiana, Widiastuti, \& Harsritanto, 2017).

Konsep compact city juga memiliki aspek kualitas hidup. Quality of life atau kualitas hidup pada konsep compact city dituntut harus baik dari segi ekonomi dan sosial. Kualitas hidup yang baik akan terpenuhi dengan adanya pemenuhan kebutuhan secara material dan juga sosial. Kebutuhan material atau yang menyangkut fisik dalam hal ini terkait dengan fasilitas sarana dan prasarana permukiman serta kondisi rumah, bidang ekonomi yang menyangkut pekerjaan dan pendapatan serta bidang sosial yang terkait dengan status kepemilikan lahan dan bangunan, lama bermukim, jumlah anggota keluarga, usia, tingkat pendidikan, motivasi, kesempatan, pemenuhan kebutuhan, serta modal sosial dan individual seseorang atau keluarga (Rahmat, 2010). Menurut Burgess dalam Jenks et. al. (2000), jika dikaitkan dengan konsep compact city, suatu kota dapat dikatakan kompak jika dapat melayani kebutuhan di dalamnya, termasuk dari segi penyediaan fasilitas umum atau 
sarana-sarana dasar sehingga diharapkan kondisi sosial ekonomi masyarakatnya juga dapat bertahan dan mengikuti perkembangan fisik kota yang sangat padat dan dinamis.

\section{METODE PENELITIAN}

Pendekatan yang dilakukan dalam penelitian ini adalah pendekatan deduktif dengan jenis penelitian kuantitatif. Teknik pengumpulan data yang digunakan dalam penelitian ini adalah teknik pengumpulan data secara sekunder untuk data yang berkaitan dengan instansi pemerintahan dan juga observasi dari citra satelit, seperti jumlah penduduk resmi kawasan, peta persebaran guna lahan, serta ketersediaan sarana dasar. Data-data tersebut digunakan untuk menganalisis masing-masing variabel penelitian, yaitu guna lahan campuran, pelayanan sarana dasar dan kepadatan kawasan. Ketiga variabel tersebut kemudian dianalisis dengan masing-masing indikatornya dan untuk mendapatkan hasil akhir dilakukan analisis skoring dengan Skala Guttmann. Indikator pada masing-masing variabel dijabarkan pada Tabel 1.

Tabel 1. Parameter dan Nilai pada Variabel Guna Lahan Campuran

\begin{tabular}{|c|c|c|c|}
\hline Variabel & Sub-Variabel & Kriteria & Skor \\
\hline \multirow{16}{*}{ Guna lahan campuran } & Penggunaan lahan pada Kelurahan Joyotakan & $\begin{array}{l}\text { Penggunaan lahan tidak campuran } \\
\text { Penggunaan lahan campuran }\end{array}$ & $\begin{array}{l}0 \\
1\end{array}$ \\
\hline & $\begin{array}{l}\text { Penggunaan lahan pada Kelurahan } \\
\text { Danukusuman }\end{array}$ & $\begin{array}{l}\text { Penggunaan lahan tidak campuran } \\
\text { Penggunaan lahan campuran }\end{array}$ & $\begin{array}{l}0 \\
1\end{array}$ \\
\hline & Penggunaan lahan pada Kelurahan Serengan & $\begin{array}{l}\text { Penggunaan lahan tidak campuran } \\
\text { Penggunaan lahan campuran }\end{array}$ & $\begin{array}{l}0 \\
1\end{array}$ \\
\hline & Penggunaan lahan pada Kelurahan Tipes & $\begin{array}{l}\text { Penggunaan lahan tidak campuran } \\
\text { Penggunaan lahan campuran }\end{array}$ & $\begin{array}{l}0 \\
1\end{array}$ \\
\hline & Penggunaan lahan pada Kelurahan Kratonan & $\begin{array}{l}\text { Penggunaan lahan tidak campuran } \\
\text { Penggunaan lahan campuran }\end{array}$ & $\begin{array}{l}0 \\
1\end{array}$ \\
\hline & Penggunaan lahan pada Kelurahan Jayengan & $\begin{array}{l}\text { Penggunaan lahan tidak campuran } \\
\text { Penggunaan lahan campuran }\end{array}$ & $\begin{array}{l}0 \\
1\end{array}$ \\
\hline & Penggunaan lahan pada Kelurahan Kemlayan & $\begin{array}{l}\text { Penggunaan lahan tidak campuran } \\
\text { Penggunaan lahan campuran }\end{array}$ & $\begin{array}{l}0 \\
1\end{array}$ \\
\hline & $\begin{array}{c}\text { Penggunaan lahan pada Kelurahan } \\
\text { Joyosuran }\end{array}$ & $\begin{array}{l}\text { Penggunaan lahan tidak campuran } \\
\text { Penggunaan lahan campuran }\end{array}$ & $\begin{array}{l}0 \\
1\end{array}$ \\
\hline & Penggunaan lahan pada Kelurahan Semanggi & $\begin{array}{l}\text { Penggunaan lahan tidak campuran } \\
\text { Penggunaan lahan campuran }\end{array}$ & $\begin{array}{l}0 \\
1\end{array}$ \\
\hline & $\begin{array}{c}\text { Penggunaan lahan pada Kelurahan Pasar } \\
\text { Kliwon }\end{array}$ & $\begin{array}{l}\text { Penggunaan lahan tidak campuran } \\
\text { Penggunaan lahan campuran }\end{array}$ & $\begin{array}{l}0 \\
1\end{array}$ \\
\hline & Penggunaan lahan pada Kelurahan Baluwarti & $\begin{array}{l}\text { Penggunaan lahan tidak campuran } \\
\text { Penggunaan lahan campuran }\end{array}$ & $\begin{array}{l}0 \\
1\end{array}$ \\
\hline & Penggunaan lahan pada Kelurahan Gajahan & $\begin{array}{l}\text { Penggunaan lahan tidak campuran } \\
\text { Penggunaan lahan campuran }\end{array}$ & $\begin{array}{l}0 \\
1\end{array}$ \\
\hline & Penggunaan lahan pada Kelurahan Kauman & $\begin{array}{l}\text { Penggunaan lahan tidak campuran } \\
\text { Penggunaan lahan campuran }\end{array}$ & $\begin{array}{l}0 \\
1\end{array}$ \\
\hline & $\begin{array}{c}\text { Penggunaan lahan pada Kelurahan Kampung } \\
\text { Baru }\end{array}$ & $\begin{array}{l}\text { Penggunaan lahan tidak campuran } \\
\text { Penggunaan lahan campuran }\end{array}$ & $\begin{array}{l}0 \\
1\end{array}$ \\
\hline & $\begin{array}{c}\text { Penggunaan lahan pada Kelurahan Kedung } \\
\text { Lumbu }\end{array}$ & $\begin{array}{l}\text { Penggunaan lahan tidak campuran } \\
\text { Penggunaan lahan campuran }\end{array}$ & $\begin{array}{l}0 \\
1\end{array}$ \\
\hline & Penggunaan lahan pada Kelurahan Sangkrah & $\begin{array}{l}\text { Penggunaan lahan tidak campuran } \\
\text { Penggunaan lahan campuran }\end{array}$ & $\begin{array}{l}0 \\
1\end{array}$ \\
\hline
\end{tabular}

Variabel guna lahan campuran pada penelitian ini diukur dengan menggunakan indeks entropi pada masing-masing kelurahan dikarenakan penggunaan lahan campuran dalam penelitian ini dilihat dalam skala lingkungan yang mencakup beberapa blok bangunan yang memungkinkan berbagai penggunaan lahan termasuk perumahan, komersial, dan industri ditempatkan bersama secara terintegrasi, yang mana dapat diartikan pada skala kelurahan (Bramiana et al., 2017). Indeks entropi (entrophy index) mengkuantifikasi keacakan, segregasi, keragaman atau kompresibilitas dalam data. Penggunaan lahan campuran menunjukkan pola kombinasi dan pemisahan dari penggunaan lahan yang berbeda, sehingga indeks entropi 
menjadi metode yang paling banyak diterima dan umum untuk digunakan dalam mewakili penggunaan lahan campuran dalam suatu area geografis (Bahadure \& Kotharkar, 2015). Menurut Frank et al dalam Bahadure \& Kortharkar (2015), rumus untuk menghitung indeks entropi digambarkan dalam persamaan seperti berikut.

$$
\text { Enthropy Index }=(-1) \times \sum_{j}\left(\frac{P_{j} \times \ln \left(P_{j}\right)}{\ln (J)}\right)
$$

Dimana,

$\mathrm{Pj} \quad=$ proporsi penggunaan lahan pada masing-masing jenis guna lahan

$\mathrm{J} \quad=$ jumlah jenis guna lahan

Indeks entropi memiliki nilai antara 0 dan 1, dimana 0 mengindikasikan single-use atau penggunaan yang homogen. Sedangkan nilai 1 menunjukkan nilai maksimum guna lahan campuran (mixed-use) atau penggunaan yang heterogen (Bahadure \& Kotharkar, 2015). Pada penelitian ini, penggunaan lahan pada suatu kelurahan diklasifikasikan memiliki guna lahan campuran (skor 1) ketika indeks entropinya memiliki nilai antara 0,5 hingga 1.

Tabel 2. Parameter dan Nilai pada Variabel Pelayanan Sarana Dasar

\begin{tabular}{|c|c|c|c|}
\hline Variabel & Sub-Variabel & Kriteria & Skor \\
\hline \multirow{9}{*}{$\begin{array}{l}\text { Pelayanan sarana } \\
\text { dasar }\end{array}$} & Pelayanan pada sarana & Radius pelayanan sarana tidak mencakup keseluruhan kawasan & 0 \\
\hline & $\begin{array}{l}\text { pemerıntahan dan pelayanan } \\
\text { umum }\end{array}$ & Radius pelayanan sarana mencakup keseluruhan kawasan & 1 \\
\hline & $\begin{array}{l}\text { Pelayanan pada sarana } \\
\text { pendidikan }\end{array}$ & $\begin{array}{l}\text { Radius pelayanan sarana tidak mencakup keseluruhan kawasan } \\
\text { Radius pelayanan sarana mencakup keseluruhan kawasan }\end{array}$ & $\begin{array}{l}0 \\
1\end{array}$ \\
\hline & $\begin{array}{l}\text { Pelayanan pada sarana } \\
\text { kesehatan }\end{array}$ & $\begin{array}{l}\text { Radius pelayanan sarana tidak mencakup keseluruhan kawasan } \\
\text { Radius pelayanan sarana mencakup keseluruhan kawasan }\end{array}$ & $\begin{array}{l}0 \\
1\end{array}$ \\
\hline & Pelayanan pada sarana & Radius pelayanan sarana tidak mencakup keseluruhan kawasan & 0 \\
\hline & $\frac{\text { perioadaalan }}{\text { Pelavanan pada sarana }}$ & $\begin{array}{l}\text { Radius pelayanan sarana mencakup keseluruhan kawasan } \\
\text { Radius nelavanan sarana tidak mencakun keseluruhan kawasan }\end{array}$ & $\frac{1}{0}$ \\
\hline & perdagangan & Radius pelayanan sarana mencakup keseluruhan kawasan & 1 \\
\hline & $\begin{array}{l}\text { Pelayanan pada sarana } \\
\text { ruang terbuka }\end{array}$ & $\begin{array}{l}\text { Radius pelayanan sarana tidak mencakup keseluruhan kawasan } \\
\text { Radius pelayanan sarana mencakup keseluruhan kawasan }\end{array}$ & $\begin{array}{l}0 \\
1\end{array}$ \\
\hline & $\begin{array}{l}\text { Pelayanan pada sarana } \\
\text { transportasi }\end{array}$ & $\begin{array}{l}\text { Radius pelayanan sarana tidak mencakup keseluruhan kawasan } \\
\text { Radius pelayanan sarana mencakup keseluruhan kawasan }\end{array}$ & $\begin{array}{l}0 \\
1\end{array}$ \\
\hline
\end{tabular}

Skoring pada variabel pelayanan sarana dasar dibagi menjadi dua, yaitu radius pelayanan sarana yang mencakup keseluruhan kawasan dan yang tidak mencakup (Tabel 2). Kriteria pelayanan sarana dikategorikan mencakup keseluruhan kawasan jika semua sarana yang sejenis, di-buffer sesuai dengan standar radius masing-masing pada SNI 03-1733-2004 (Badan Standarisasi Nasional, 2004), hasil buffer tersebut mencakup keseluruhan kawasan BWK I Kota Surakarta (skor 1). Sedangkan, jika terdapat sarana yang buffer radiusnya tidak mencakup keseluruhan kawasan, maka jenis sarana tersebut dikategorikan tidak mencakup keseluruhan kawasan (skor 0).

Tabel 3. Parameter dan Nilai pada Variabel Kepadatan Kawasan

\begin{tabular}{|c|c|c|c|}
\hline Variabel & Sub-Variabel & Kriteria & Skor \\
\hline \multirow{4}{*}{ Kepadatan kawasan } & \multirow{2}{*}{ Kepadatan penduduk } & Kepadatan penduduk rendah - sedang & 0 \\
\hline & & Kepadatan penduduk tinggi - sangat padat & 1 \\
\hline & \multirow{2}{*}{ Kepadatan lahan terbangun } & Kepadatan lahan terbangun rendah - sedang & 0 \\
\hline & & Kepadatan lahan terbangun tinggi - sangat padat & 1 \\
\hline
\end{tabular}

Analisis kepadatan kawasan yang dilakukan dengan perhitungan kepadatan penduduk bersih dengan cara membagi jumlah penduduk dengan luas wilayah dan juga dari besaran kepadatan lahan terbangun yang dilakukan dengan cara membagi jumlah penduduk dengan total luas lahan terbangun yang terbatas pada luas lantai dasar pada kawasan. Kemudian dari hasil perhitungan tersebut dikategorikan dengan indikator yang mengikuti ketentuan tingkat kepadatan menurut SNI 031733-2004 yang memiliki 4 kategori tingkatan, yaitu kepadatan rendah (<150 jiwa/ha), kepadatan sedang (151-200 jiwa/ha), 
kepadatan tinggi (201-400 jiwa/ha) dan sangat padat (>400 jiwa/ha) (Badan Standarisasi Nasional, 2004). Pada analisis skoring, variabel kepadatan kawasan dikategorikan menjadi kepadatan rendah - sedang dan kepadatan tinggi - sangat padat. Hal ini dikarenakan pada konsep compact city, terdapat istilah high density compact living, yang berarti tempat tinggal yang kompak berkepadatan tinggi, sehingga kepadatan kawasan harus tergolong tinggi. Maka dari itu, tingkat kepadatan rendah sedang dianggap tidak memiliki potensi implementasi compact city dengan diberi skor 0 dan untuk kepadatan tinggi dan seterusnya, diberi skor 1 (Tabel 3).

Pada penelitian ini, setiap sub-variabel memiliki nilai maksimal 1 dan nilai minimal 0 . Pada variabel penggunaan lahan campuran yang memiliki sub-variabel berjumlah 16 , maka skor maksimalnya adalah 16 . Kemudian variabel pelayanan sarana dasar memiliki 7 sub-variabel sehingga memiliki total skor 7 dan variabel kepadatan kawasan memiliki 2 sub-variabel sehingga memiliki total skor 2. Maka dari itu, total skoring pada penelitian ini adalah $25=100 \%$. Oleh karena itu, penelitian ini menggunakan Skala Guttman, maka diambil titik kesesuaian dengan rentang $50 \%$, dimana jika hasil total skoring penelitian 0-50\% dianggap memiliki potensi dan jika $>50 \%$ maka dinyatakan memiliki potensi (Sakai, 2016). Kemudian hasil tersebut dijelaskan secara deskriptif untuk memberikan gambaran terkait potensi implementasi compact city pada BWK I Kota Surakarta.

\section{HASIL DAN PEMBAHASAN}

Analisis yang dilakukan dalam penelitian ini berbeda pada tiap variabel, yaitu analisis penggunaan lahan pada tiap kelurahan untuk variabel guna lahan campuran, analisis ketersediaan dan jangkauan pada masing-masing sarana dasar untuk variabel pelayanan sarana dasar dan analisis kepadatan penduduk bersih dan kepadatan lahan terbangun untuk variabel kepadatan kawasan.

\subsection{PENGGUNAAN LAHAN CAMPURAN}

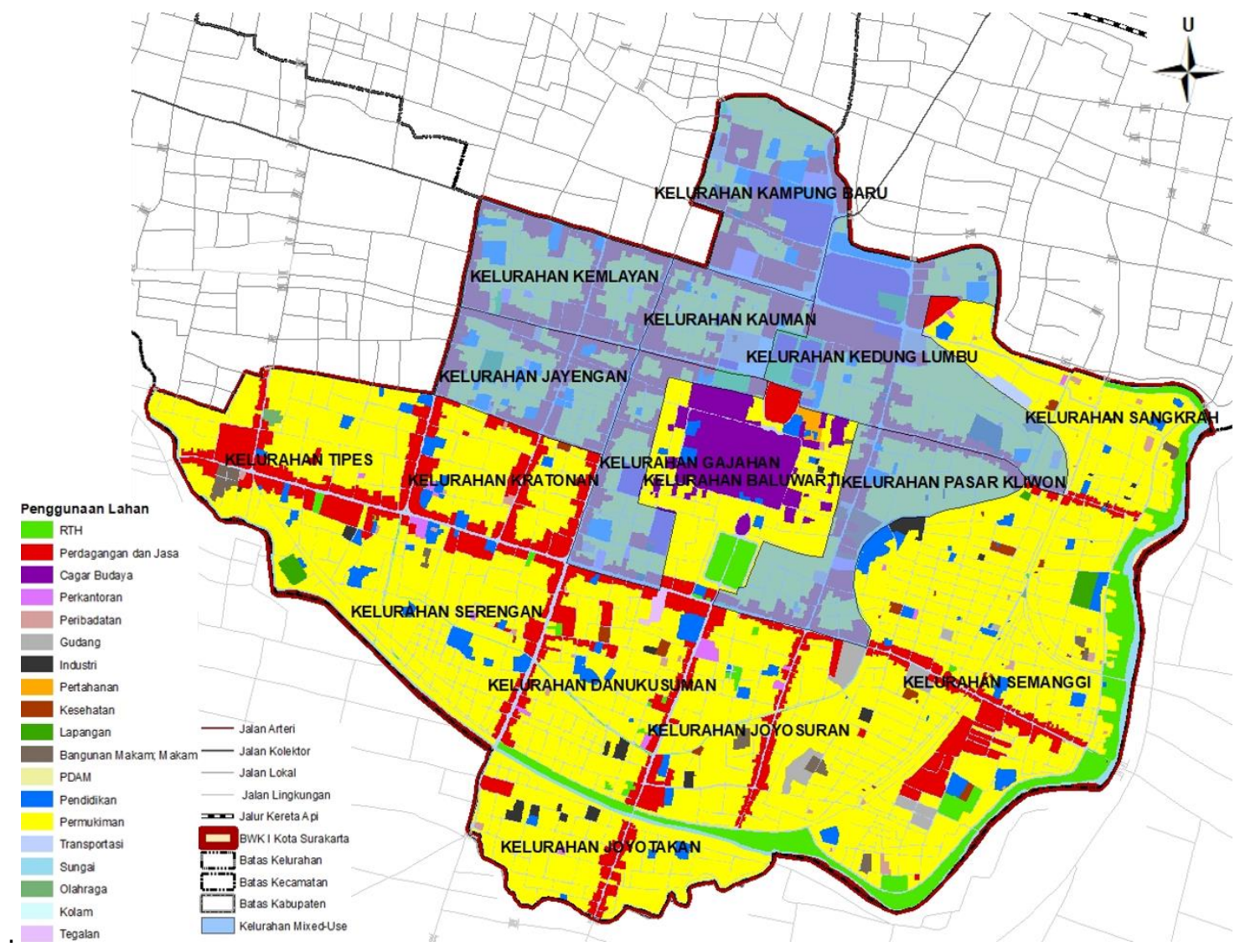

Gambar 1. Peta Hasil Analisis Penggunaan Lahan Campuran pada BWK I Kota Surakarta 
Pada konsep compact city diperlukan adanya penggunaan lahan yang campuran (mixed-use) sebagai salah satu kriteria konsep ini dapat diimplementasikan. Konsep compact city menitikberatkan kepada adanya penggunaan lahan campuran (mixed-use development) sehingga dapat mereduksi perjalanan penduduk untuk mencegah adanya perkembangan kota yang meluas ke daerah pinggirannya (Jenks \& Burgess, 2000). Dalam konteks penelitian ini, penggunaan lahan campuran dilihat dalam skala lingkungan yang mencakup beberapa blok bangunan yang memungkinkan berbagai penggunaan lahan termasuk perumahan, komersial, dan industri ditempatkan bersama secara terintegrasi (dalam penelitian ini kelurahan) (Bramiana et al., 2017).

Berdasarkan hasil analisis penggunaan lahan yang dilakukan pada 16 kelurahan pada BWK I Kota Surakarta, didapatkan hasil bahwa hanya 7 kelurahan yang memiliki penggunaan lahan campuran dan 9 kelurahan lainnya belum memenuhi kriteria guna lahan campuran. Hal ini menunjukkan hasil pengukuran pada variabel guna lahan campuran pada BWK I Kota Surakarta belum maksimal dalam mendukung implementasi compact city. Adapun kelurahan-kelurahan yang sudah dapat dikategorikan memiliki penggunaan lahan campuran adalah Kelurahan Jayengan, Kemlayan, Pasar Kliwon, Gajahan, Kauman, Kampung Baru dan Kedung Lumbu. Ketujuh kelurahan tersebut diklasifikasikan sebagai kelurahan dengan penggunaan lahan campuran dikarenakan memiliki indeks entropi lebih dari 0,5 dengan pola penggunaan lahannya beragam pada ruas-ruas jalannya. Maka dari itu, hasil analisis penggunaan lahan campuran pada BWK I Kota Surakarta memiliki nilai 7.

Kemudian, dapat dilihat bahwa kelurahan-kelurahan yang memiliki penggunaan lahan campuran ini lokasinya berdekatan (Gambar 1). Area dimana kelurahan-kelurahan ini berdekatan dapat dikategorikan sebagai pusat aktivitas kawasan yang kemudian dapat mempengaruhi kelurahan-kelurahan lain di sekitarnya untuk memulai pemanfaatan lahan campuran, sehingga nantinya secara keseluruhan diharapkan BWK I Kota Surakarta dapat meningkatkan tingkat penggunaan lahan yang campuran untuk mengakomodir lebih banyak aktivitas internal kawasan.

\subsection{PELAYANAN SARANA DASAR}

Pada konsep compact city dibutuhkan pelayanan sarana dasar yang memadai untuk mendukung implementasinya. Pelayanan sarana dasar pada suatu kawasan harus memenuhi keseluruhan kebutuhan dasar pendudukknya, sehingga suatu kawasan kota tersebut dapat menjamin kualitas hidup penduduknya (Jenks \& Burgess, 2000). Pelayanan sarana dasar pada suatu kawasan dapat diukur dengan standar radius pelayanan dari SNI 03-1733-2004.

Pada BWK I Kota Surakarta, hanya terdapat 3 dari 7 jenis sarana dasar yang semua sarananya mencakup keseluruhan kawasan BWK I Kota Surakarta (Lampiran). Sarana-sarana tersebut adalah sarana peribadatan, perdagangan dan jasa, serta pendukung transportasi. Sedangkan untuk 4 jenis sarana dasar lain, tidak semua sarananya mencakup keseluruhan kawasan jika dilihat dari ketersediaan dan cakupan radiusnya dan juga masih kurang dari standar minimum jumlah ketersediaan sarana. Pada sarana pemerintahan dan pelayanan umum, terdapat sarana pos pemadam kebakaran yang ketersediaannya belum mencukupi keseluruhan kawasan. Pada sarana pendidikan, semua jenis sarananya belum memenuhi dari segi ketersediaan. Sedangkan untuk jangkauan, terdapat taman kanak kanak dan sekolah menengah pertama yang cakupannya belum memenuhi keseluruhan kawasan. Kemudian pada sarana kesehatan, terdapat posyandu yang dari segi ketersediaan belum memenuhi dan buffer radiusnya juga belum mencakup keseluruhan kawasan. Terakhir, pada sarana ruang terbuka terdapat sarana taman yang jangkauannya belum mencakup keseluruhan kawasan. Kondisi ketersediaan dan cakupan pelayanan sarana dasar yang belum memenuhi seperti ini menunjukkan bahwa persebaran sarana dasar pada BWK I Kota Surakarta masih kurang merata dan belum maksimal untuk mendukung implementasi konsep compact city. Pada beberapa jenis sarana, persebarannya cukup terpusat pada pusat kawasan, sehingga pada pinggiran kawasan BWK I Kota Surakarta tidak tercakupi (untuk persebaran dan jangkauan sarana, peta dapat dilihat pada lampiran). Maka dari itu, diperlukan penyediaan sarana yang lebih merata terutama penambahan sarana pada ujung-ujung kawasan.

\subsection{KEPADATAN KAWASAN}

Kepadatan kawasan pada konsep compact city terdiri dari kepadatan penduduk bersih dan kepadatan lahan terbangun. Kepadatan penduduk bersih dihitung dari jumlah penduduk kawasan dibagi dengan luas total permukiman pada kawasan. BWK I Kota Surakarta memiliki total 139.052 jiwa penduduk berdasarkan data dari Kecamatan Serengan dan Kecamatan Pasar Kliwon dalam Angka Tahun 2019. Sedangkan, untuk luas total permukiman pada BWK I Kota Surakarta berdasarkan 
penggunaan lahannya adalah sebesar 455,82 hektar. Maka dari itu, dihasilkan kepadatan penduduk bersih BWK I Kota Surakarta adalah sebesar 305,05 jiwa/ha yang pada SNI 03-1733-2004 diklasifikasikan sebagai kepadatan tinggi (Badan Standarisasi Nasional, 2004). Kepadatan tinggi jika disesuaikan dengan skor klasifikasi kepadatan penduduk maka memiliki nilai 1. Kemudian untuk kepadatan lahan terbangun dihitung dari jumlah penduduk dibagi dengan luas total lahan terbangun pada BWK I Kota Surakarta. Seperti yang sudah diketahui, jumlah penduduk kawasan adalah 139.052 jiwa. Sedangkan, untuk luas total lahan terbangun pada kawasan adalah sebesar 744,5 hektar. Maka dari itu, dihasilkan kepadatan lahan terbagun BWK I Kota Surakarta sebesar 186,8 jiwa/ha yang pada SNI 03-1733-2004 diklasifikasikan sebagai kepadatan sedang dengan skor 0 (Badan Standarisasi Nasional, 2004).

Pada konsep compact city, diperlukan adanya bentuk kota yang padat untuk mereduksi panjang perjalanan penduduk internal kawasan (Jenks \& Burgess, 2000). Oleh karena itu, kepadatan dengan klasifikasi di bawah kepadatan tinggi dianggap tidak dapat mendukung implementasi compact city. Nilai kepadatan yang kurang tinggi pada kepadatan lahan terbangun dapat mengindikasikan bahwa lahan terbangun pada BWK I Kota Surakarta masih kurang dimanfaatkan secara maksimal oleh penduduk internal kawasan dan belum dapat secara maksimal untuk menjadi variabel pendukung compact city. Oleh karena itu, jika BWK I Kota Surakarta ingin mengimplementasikan konsep compact city, nilai kepadatan lahan terbangun masih perlu ditingkatkan agar dapat memenuhi kriteria implementasi compact city dengan memaksimalkan pemanfaatan lahan terbangun yang sudah tersedia terlebih dahulu, daripada membangun lahan yang baru untuk perkembangan kawasan ke depannya.

\subsection{POTENSI IMPLEMENTASI COMPACT CITY PADA BWK I KOTA SURAKARTA}

Nilai potensi implementasi compact city pada BWK I Kota Surakarta didapat dari total nilai hasil pengukuran ketiga variabel guna lahan campuran, pelayanan sarana dasar dan kepadatan kawasan. Pada variabel guna lahan campuran didapat nilai skoring 7, pelayanan sarana dasar memiliki nilai 3, dan kepadatan kawaasan memiliki nilai 1. Maka dari itu, BWK I Kota Surakara untuk saat ini belum memiliki potensi untuk diimplementasikan konsep compact city dengan total nilai hasil skoring 11 , dengan persentase $44 \%$ dari total skor maksimum.

BWK I Kota Surakarta memiliki berbagai isu terkait pertumbuhan kota yang cenderung horizontal, seperti adanya permasalahan kemacetan, kepadatan tidak merata pada titik-titik tertentu dan kualitas hidup penduduk yang masih kurang jika dilihat dari masih banyak permukiman padat yang kurang layak. Berdasarkan isu-isu tersebut, diasumsikan konsep compact city dapat menjadi solusi permasalahan-permasalahan tersebut. Namun setelah dilakukan pengukuran terkait variabel-variabel yang mendukung implementasi compact city, BWK I Kota Surakarta diklasifikasikan sebagai tidak memiliki potensi dikarenakan masih kurang memenuhi indikator pada setiap variabel. Pada konsep compact city, penggunaan lahan yang dapat berpotensi mendukung implementasinya adalah penggunaan lahan campuran. Penggunaan lahan campuran ini penting untuk mendefinisikan aspek bentuk kota yang terpusat pada konsep compact city. Pada BWK I Kota Surakarta, hanya sebagian kecil dari keseluruhan kawasan yang memiliki penggunaan lahan campuran. Sedangkan sebagian penggunaan lahan masih cenderung homogen, terutama pada pinggiran kawasan. Kemudian untuk pelayanan sarana dasar juga masih sangat terpusat pada tengah kawasan. Sedangkan untuk daerah pinggiran kota, terutama yang berbatasan langsung dengan Kabupaten Sukoharjo, masih kurang memadai dari segi ketersediaan dan jangkauan pelayanan. Selain itu, dari segi kepadatan kawasan, untuk kepadatan penduduk bersih sudah memenuhi kriteria padat, namun kepadatan lahan terbangun masih kurang. Hal ini mengindikasikan bahwa penduduk yang tinggal pada BWK I Kota Surakarta masih belum memaksimalkan lahan terbangun yang ada untuk pemenuhan kebutuhan sehari-hari.

\section{KESIMPULAN}

Compact city merupakan suatu konsep untuk mengelola pertumbuhan kota agar lebih efisien dengan menerapkan pembangunan intensif dengan guna lahan campuran, sehingga dapat mereduksi perjalanan penduduk kawasan. Untuk itu, penggunaan lahan, pelayanan sarana, serta intensifikasi pembangunan dalam kawasan menjadi faktor-faktor penting untuk mendukung implementasi konsep compact city. Pada Kota Surakarta, konsep compact city dapat menjadi salah satu solusi untuk isu perkotaan yang terjadi. Isu perkotaan tersebut terkait adanya pertumbuhan kota yang cenderung kurang terkendali dan melebar ke daerah peri-urban yang terjadi khususnya pada BWK I Kota Surakarta. Pada BWK I Kota Surakarta terjadi isu-isu perkotaan, seperti kepadatan penduduk yang tinggi, yang dapat menjadi indikasi pendukung implementasi compact city pada BWK I Kota Surakarta. Hal ini dikarenakan intensifikasi dalam konsep compact city dapat dilihat dari kepadatan. 
Namun, jika ditinjau secara keseluruhan, faktor yang dapat mendukung implementasi compact city terkait kepadatan tidak hanya dilihat dari kepadatan penduduk namun juga dari kepadatan lahan terbangun. Dari segi kepadatan terbangun, BWK I Kota Surakarta masih belum dapat dikategorikan tinggi, sehingga secara keseluruhan kepadatan kawasan BWK I Kota Surakarta belum dapat mendukung implementasi compact city. Kemudian, ditinjau dari pelayanan sarana dasar, kota yang berpotensi untuk diimplentasikan compact city harus dapat memenuhi kebutuhan penduduknya. Pada BWK I Kota Surakarta, ketersediaan dan jangkauan sarana dasar juga masih belum dapat mencakupi keseluruhan kawasan, sehingga masih belum optimal untuk mendukung implementasi compact city. Selain itu dari segi guna lahan, implementasi compact city didukung dengan adanya guna lahan campuran. Pada BWK I Kota Surakarta, bagian kawasan yang memenuhi kriteria campuran hanya sebagian kecil yang mengarah ke pusat Kota Surakarta. Sedangkan, untuk sebagian besar kawasan, terutama yang mengarah ke perbatasan kabupaten lain masih cenderung homogen untuk penggunan lahannya.

Dari pembahasan terkait hasil analisis ketiga variabel untuk mengukur potensi implementasi compact city tersebut, dapat diambil kesimpulan bahwa BWK I Kota Surakarta belum memiliki potensi untuk diimplementasikan konsep compact city. Namun demikian, tidak menutup kemungkinan bahwa pada masa yang akan datang BWK I Kota Surakarta dapat berpotensi untuk dilakukan implementasi compact city dengan perlu beberapa peningkatan dan penyesuaian baik dari segi guna lahan, pelayanan sarana dan intensifikasi atau kepadatan kawasan

\section{DAFTAR PUSTAKA}

Adisasmita, R. (2006). Pembangunan Pedesaan dan Perkotaan. Yogyakarta: Graha IImu.

Badan Pusat Statistik. (2018). Kota Surakarta dalam Angka Tahun 2018. Retrieved from https://surakartakota.bps.go.id/publication/2018/08/16/c3a56b56c074228d1b0e90e0/kotasurakarta-dalam-angka-2018.html

Badan Standarisasi Nasional. (2004). SNI 03-1733-2004 tentang Tata cara perencanaan lingkungan perumahan di perkotaan. Retrieved from http://nawasis.org/portal/download/digilib/369-SNI-2004_1733_03.pdf

Bahadure, S., \& Kotharkar, R. (2015). Assessing Sustainability of Mixed Use Neighbourhoods through Residents' Travel Behaviour and Perception: The Case of Nagpur, India. Sustainability, 7(9), 12164-12189. https://doi.org/10.3390/su70912164

Bramiana, C. N., Widiastuti, R., \& Harsritanto, B. I. (2017). Implementing Mixed Land Use Rooting Jane Jacobs' Concept of Diversity in Urban Sustainability. Modul, 17(1), 27-35. https://doi.org/doi: 10.14710/mdl.17.1.2017.27-35

Desiyana, I. (2017). Urban Sprawl Dan Dampaknya Pada Kualitas Lingkungan : Studi Kasus Di Dki Jakarta Dan. Jurnal Komunikasi Visual ULTIMART, 9(2), 16-24. https://doi.org/10.31937/ultimart.v9i2.745

Hanief, F., \& Dewi, S. P. (2014). Pengaruh Urban Sprawl Terhadap Perubahan Bentuk Kota Semarang Ditinjau Dari Perubahan Kondisi Fisik Kelurahan Meteseh Kecamatan Tembalang. Ruang, 2(1), 341-350. Retrieved from https://ejournal3.undip.ac.id/index.php/ruang/article/view/4367

Horn, A. (2015). Urban Growth Management Best Practices: Towards Implications for the Developing World. International Planning Studies, 20(1-2), 131-145. https://doi.org/10.1080/13563475.2014.942513

Jacobs, J. (1961). The Death and Life of Great American Cities. New York: Random House.

Jenks, M., \& Burgess, R. (2000). Compact Cities: Sustainable Urban Forms for Developing Countries. London: Spoon Press. https://doi.org/10.4324/9780203478622

Jenks, M., Burton, E., \& Williams, K. (1996). The Compact city: A Sustainable Urban Form? London: Spoon Press. https://doi.org/10.4324/9780203362372

Jensen, J. O., Christensen, T. H., \& Gram-Hanssen, K. (2011). Sustainable urban development: Compact cities or consumer practices? Danish'Journal'of'Geoinformatics'and'Land'Management, $\quad 46(1), \quad 50-64 . \quad$ Retrieved from https://kth.instructure.com/courses/20776/files/2987124/download?verifier=gAp9A0IGPOUINDanyVH7C7O6kGcQagWPDynvkjJG \&wrap $=1$

Rahmat, S. (2010). Pengaruh Perubahan Kualitas Hidup Terhadap Orientasi Kebutuhan Rumah pada Perumahan BTN Somba 3 Kota Bulukumba (Universitas Diponegoro). Universitas Diponegoro. Retrieved from http://eprints.undip.ac.id/23677/

Saaty, T. L., \& De Paola, P. (2017). Rethinking Design and Urban Planning for the Cities of the Future. Buildings, 7(3), 76. https://doi.org/10.3390/buildings7030076

Sakai, R. (2016). Analisis Efektifitas Jembatan Penyeberangan di Jalan S.Parman (Samping Mall Lembuswana) Samarinda. ..EJournal Teknik Sipil Dan Arsitektur, 2(2), 1-15. Retrieved from http://ejurnal.untag-smd.ac.id/index.php/TEK/article/view/2469

Setioko, B. (2009). Growth of Urban Sprawl in Finger Areas (Case Study: Semarang City). ClB Working Commission W110 Informal Settlements and Affordable Housing, II79-II87. Retrieved from https://www.irbnet.de/daten/iconda/CIB_DC25377.pdf

Zahnd, M. (2006). Perancangan Kota Secara Terpadu. Yogyakarta: Kanisius. 
Desa-Kota, Vol. 3, No. 1, 2021, 122-132

LAMPIRAN

\section{Peta Hasil Analisis Pelayanan Sarana Dasar pada BWK I Kota Surakarta}
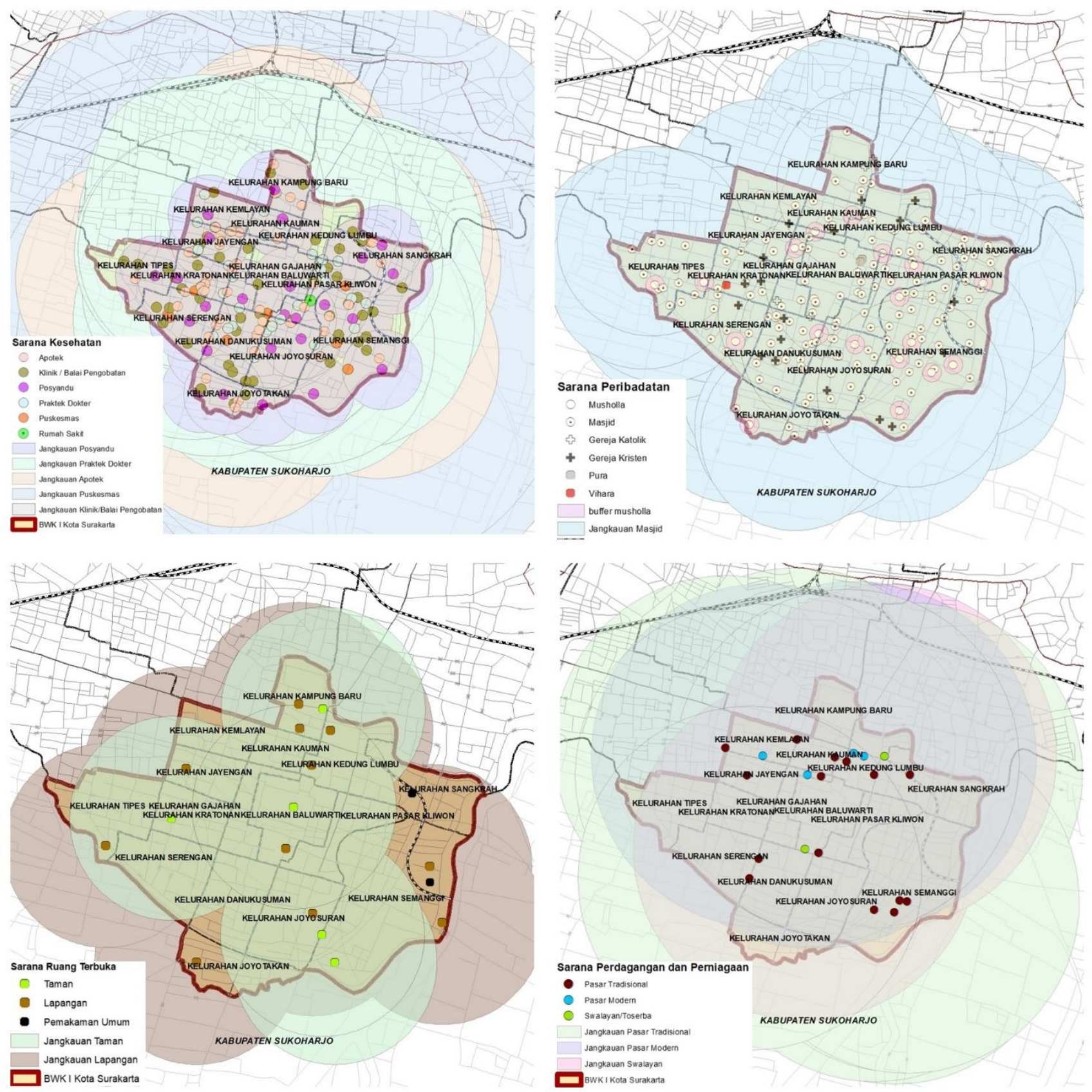

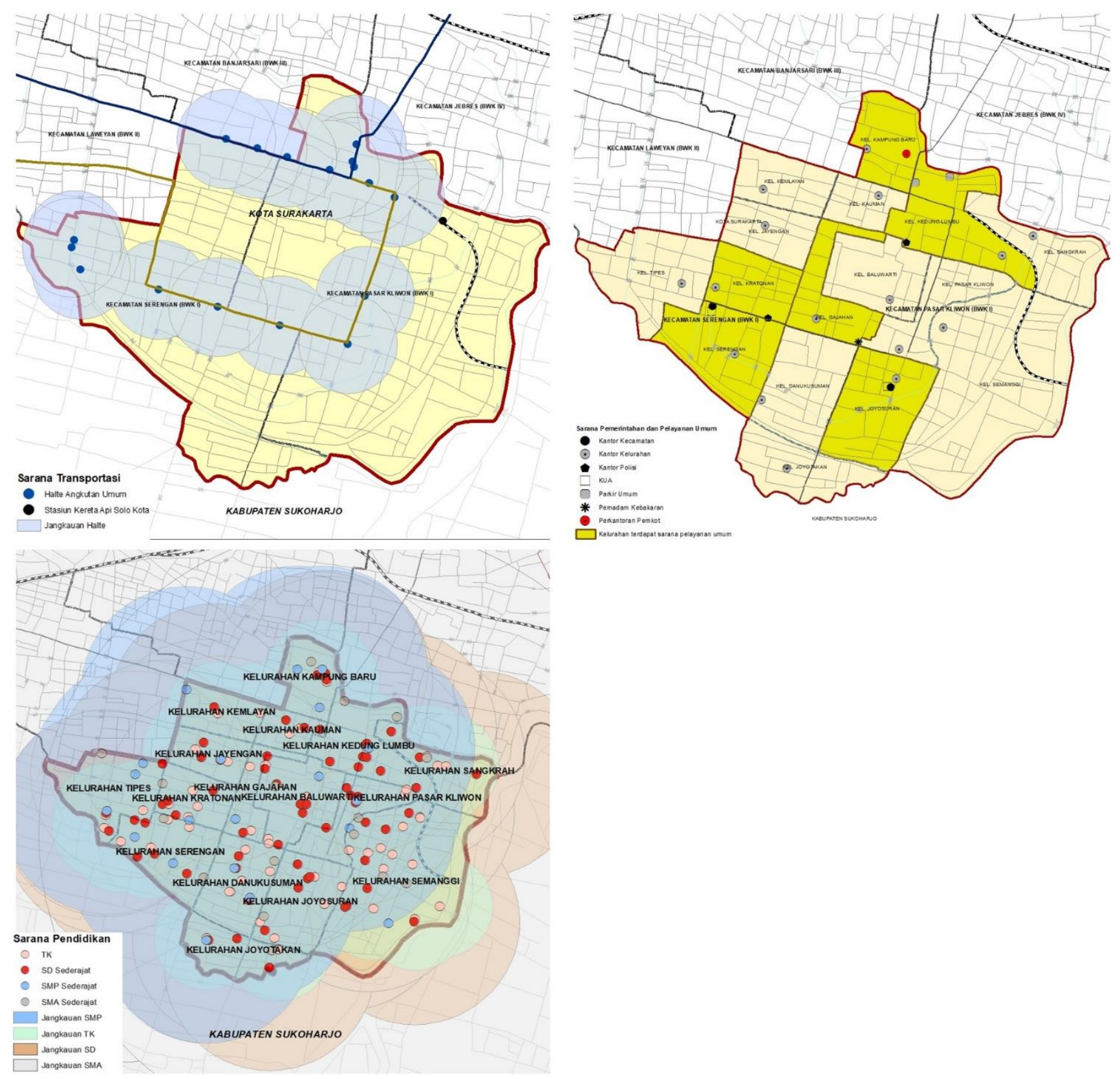